\title{
Bratman i prakseologia minimalna
}

Piotr Makowski (Uniwersytet im. Adama Mickiewicza w Poznaniu)

Powyższy tytuł dla tekstu - krótkiego wprowadzenia ${ }^{1}$ do teorii intencji opartej na planowaniu Michaela Bratmana - mógłby czytelnika, który w niewielkim choć stopniu rozeznaje się w filozofii Bratmana i wie, czym ogólnie jest prakseologia, wprawić w zdziwienie. Co amerykański współczesny filozof działania ma wspólnego z podstarzałą prakseologią? Otóż, ma dość sporo.

Michael Bratman, uczeń Donalda Davidsona, należy do czołowych współczesnych postaci w filozofii działania, a szczególnie tej jej części, którą określa się jako teorię intencji opartej na planowaniu (ang. Planning theory of intention). Specyfika, swoistość i wartość jego podejścia polegają na połączeniu problematyki planowania działania z filozofią intencjonalności i intencji. Mianowicie, plany działań Bratman rozumie jako „rozrośnięte intencje" (Bratman 1987, 8)², co nie tylko sytuuje zagadnienie planu działania w kontekście psychologicznym, ale również w interesujący sposób temporalizuje kwestię intencji. Jedno i drugie posiada sporą wagę $\mathrm{w}$ teorii działania. Zabieg taki wykonuje bowiem za jednym zamachem dwie filozoficzne rzeczy: po pierwsze, jednoznacznie wskazuje grunt metodologiczny dla teorii działania w postaci teorii intencjonalności (szerzej: filozofii psychologii) ${ }^{3}$, po drugie, prowadzi szlak badań nad działaniem w kierunku podmiotowości praktycznej rozumianej konsekwentnie diachronicznie, tj. ubranej w takie szaty pojęciowe, które oddają każdorazowo rozciagnięty $w$ czasie charakter działania ${ }^{4}$. Intencje i planowość działania wymagają - szczególnie wtedy, gdy uwyraźnimy ich czasowy charakter określonych wytycznych normatywnych. W innym wypadku działanie byłoby na dłuższą metę niemożliwe właśnie jako działanie zanurzone w czasie. W tym

\footnotetext{
1 Wstęp do: Bratman, M. E. 2013. "Płodność działalności planowanej". Przeł. P. Makowski. Ethics in Progress Vol. 4 Issue 2. Praca nad niniejszym artykułem oraz przekładem eseju Bratmana odbywała się $w$ ramach wsparcia, jakie otrzymałem $w$ ramach Stypendium Fulbrighta oraz grantu Narodowego Centrum Nauki (DEC2011/03/B/HS4/04162).

2 Odsyłacze do dzieła Bratmana podaję jedynie wówczas, gdy odnoszą się do tekstów innych, niż ten, któremu poświęcone jest niniejsze opracowanie.

3 Taki właśnie grunt nie jest dla teorii działania - przynajmniej historycznie rzecz biorąc - oczywisty.

${ }^{4}$ Bratman odwołuje się do pracy Michaela Thompsona, gdy wzmiankuje krytykę atomistycznego rozumienia działania. Warto pamiętać, że przed Thompsonem na tę kwestię równie wyraźnie zwracali uwagę Alasdair MacIntyre czy Rüdiger Bittner.
} 
miejscu ujawnia się chyba najbardziej prakseologiczny charakter teorii Bratmana.

W Płodności działalności planowanej - eseju, który można uznać poniekąd za zbierający główne motywy z jego teorii działania proponowanej od lat 80. minionego stulecia - Bratman rozpatruje działanie w kategoriach, które z pewnością przypadłyby do gustu ojcowi prakseologii, Tadeuszowi Kotarbińskiemu. Między propozycją Kotarbińskiego i Bratmana istnieją interesujące podobieństwa. Zbieżności dotyczą kwestii tak podstawowych (np. pojęcia podmiotu działania, działania, sytuacji wyboru), jak i zasadniczych (norm działania). Nie będę tu zajmował się analizą wszystkich tych podobieństw oraz różnic ${ }^{5}$, wskażę jedynie na wybrane podobieństwa, czyniące z Bratmana prakseologa (jak też zobaczymy: prakseologa minimalistę).

Zarówno Bratman jak i Kotarbiński pojmują podmiotowość praktyczną (tzn. podmiot działający) w sposób szeroki: podmiotami działającymi są nie tylko ludzie, ale i wyższe zwierzęta (Kotarbiński 1955, 33). Również problem praktycznych wyborów ujmowany jest przez obu autorów od tej samej strony: sytuacje wyboru $\mathrm{z}$ reguły wiążą się $\mathrm{z}$ możliwością potencjalnie równoprawnych alternatyw praktycznych (embarras de richesse). Prowadzi to do sytuacji osiołka Buridana (Kotarbiński 1955, 63-65), z której jednak potrafimy zwykle wyjść bezproblemowo, m.in. dzięki sprawnie działającemu czynnikowi intelektualnemu, który przenika nasze aktywności i jest z nich zasadniczo nieusuwalny (Kotarbiński 1955, 244)6. Co do takich kwestii Bratman i Kotarbiński są zgodni. Główne podobieństwo między teorią działania tego pierwszego i prakseologią tego drugiego dotyczy jednak koncepcji planowania, z którą wiążą się wyżej wspomniane, najogólniejsze normatywne wytyczne działania ${ }^{7}$.

Trzy zdolności praktyczne, które absorbują uwagę amerykańskiego filozofa w Płodności działalności planowanej - zdolność do działalności rozciągniętej w czasie, zdolności do działania kolektywnego oraz zdolność do samorządności (kierowania sobą) mają swoją głębszą podstawę i ugruntowanie $\mathrm{w}$ transcendentalnej ${ }^{8}$ zdolności do działalności planowanej.

${ }^{5}$ Kwestię tę poruszam od strony filozoficznej w (Makowski, w przygotowaniu A).

6 Jest to motyw niezwykle mocno podkreślany przez "drugą falę" prakseologii (Gasparski); jest również wyraźnie obecny w najnowszych pracach badaczy amerykańskich zajmujących się modną problematyką know-how.

${ }^{7}$ Paradoksalnie, jest to również punkt, w którym różnice między propozycją Bratmana i Kotarbińskiego uwidaczniają się chyba najjaskrawiej - ze względu na specyfikę filozofii praktycznej tego drugiego. Kwestię tę szeroko omawiam w (Makowski, w przygotowaniu A), gdzie daję również filozoficzne wytłumaczenie faktu, iż prakseologia Kotarbińskiego nie spotkała się $\mathrm{z}$ międzynarodowym uznaniem w podobnym stopniu, w jakim było to udziałem innych propozycji z kręgu Szkoły Lwowsko-Warszawskiej.

8 Sygnalizuję, że Bratmanowską tezę o zdolności do działania planowego można potraktować jako ujęcie pewnego inwariantu antropologicznego w duchu „miękkiego" transcendentalizmu (proweniencji Fichteańskiej). Pewne uwagi na temat tak 
Zdolność ta w praktyce musi - by faktycznie mogła być urzeczywistniona jako pewien rodzaj praktyki - podlegać swoistym normom. Bratman wskazuje na cztery rodzaje zależności, które w architektonice działalności planowanej mają wyraźnie normatywny charakter: konsekwencja (wewnętrzna i zewnętrzna), spójność środków i celu, stabilność oraz skupienie. Co dla jego podejścia kluczowe, normy te są proponowane z poziomu teorii intencji, są więc zarazem normami intencji (tj. zamiarów - por. uwagi translatorskie $\mathrm{w}$ tekście). Twierdzę, że w zasadzie każdą z tych norm można odnaleźć w nieźle opracowanej postaci w dziele Kotarbińskiego. Nim to wyjaśnię, warto krótko scharakteryzować owe normy.

Konsekwencję oraz spójność środków i celu można potraktować jako dość standardowe wymogi racjonalności instrumentalnej, choć są one tu, pamiętajmy, standardami zawsze dla intencji podmiotowości określonej temporalnie. Bez nich nie byłoby możliwe wykonanie czegokolwiek w czasie w sposób zamierzony. Jeśli zamierzasz iść na kawę z Gosią w przyszły piątek, to musisz wiedzieć, czy jest to wykonalne - np. ze względu na czas, miejsce i chęci Gosi. Twoje zamiary muszą być zgodne z przekonaniami co do danego stanu rzeczy. Jest to konsekwencja zewnętrzna intencji. To, co chcesz zrobić $\mathrm{w}$ przyszłym tygodniu, określa twoje zachowania teraz czy jutro. Intencja pójścia na kawę z Gosią przesądza - w pewnych granicach i do pewnego stopnia - o tym, jakie intencje masz $\mathrm{w}$ chwili obecnej. I odwrotnie - intencje posiadane teraz wpływają na spektrum możliwych intencji i wyborów później. Jest to konsekwencja wewnętrzna intencji - niesprzeczność tego, co zamierzasz. Zależności te dotyczą oczywiście również „intencji rozrośniętych”, czyli mniej lub bardziej dalekosiężnych i życiowo znaczących planów.

Spójność środków i celu, w uproszczeniu rzecz ujmując, uzupełnia normę konsekwencji w intencjach i planowaniu. Jej działanie jest zarówno „punktowe” (czyni działania koherentnymi w wycinkach czasu, synchronicznie), jak i „sieciowe” (czyni działania spójnymi diachronicznie). Jeżeli zamierzasz iść z Gosią w piątek na kawę, środki, które możesz wziąć pod uwagę, by tę intencję zrealizować, nie są dowolne, muszą być dobrane tak, by ów zamiar wspierały. Tak rozumiana spójność stanowi gwarancję elementarnego powodzenia naszych przedsięwzięć.

Konsekwencja oraz spójność środków i celu, jako normy intencji i planów, tworzą najbardziej elementarny zrąb dla konstrukcji temporalnie ujętej podmiotowości. Mówiąc metaforycznie, tkają one sieć praktycznego wymiaru naszej podmiotowości. Metafora sieci pokazuje, że modyfikowanie pojedynczych intencji i planów jest $\mathrm{z}$ reguły w jakiś (mniej lub bardziej poważny) sposób powiązane z wpływem na to, jak nasza podmiotowość się kształtuje globalnie. Nie da się jej bowiem zmieniać bez uwzględnienia tego, w

rozumianego transcendentalizmu czytelnik znajdzie w (Makowski 2012, rozdziały $2.4 .2,5.1 .1,5.1 .2)$. 
jakim stanie znajduje się ona jako całość posiadająca swoją osobistą historię oraz tego, jak zmiana ta wpływa na jej aktualną „konstrukcję”.

Normę stabilności intencji oraz planów można zrazu potraktować jako jedynie wspierającą konsekwencję ora spójność. Stabilność planu to gwarancja tego, że to, co zamierzyliśmy dziś względem tego, co ma się zdarzyć za miesiąc, będzie również naszym zamiarem jutro i później. Adekwatne ujęcie tej kwestii oznacza jednak również tezę o konserwującym charakterze, jeśli chodzi o wyżej wspomniane tkanie sieci naszej podmiotowości. Innymi słowy, stabilność intencji określa immanentną podatność planów na inercję (Bratman mówi tu też o „efekcie kuli śniegowej”). Mówiąc inaczej, jesteśmy psychologicznie predysponowani do swoistego „konserwatyzmu w praktyce"10, gdyż istnieją dla nas racje pro tanto, by trzymać się wcześniej powziętych zamiarów.

Wreszcie, norma skupienia - najciekawsza w Bratmanowskim zestawie norm intencji i planów. Psychologia podmiotowości planującej ma to do siebie, że umożliwia zamiar, zaplanowanie oraz skuteczne wykonanie dwóch lub więcej działań „za jednym zamachem”:

Jeżeli w tym samym czasie podmiot $\mathrm{P}$ (racjonalnie) zamierza $\varphi 1 \mathrm{i}$ (racjonalnie) zamierza $\varphi 2$, to powinno być możliwe dla $\mathrm{P}$ racjonalnie zamierzać $\varphi 1$ i $\varphi 2$.

Na tym właśnie polega racjonalna aglomeratywność intencji, czyli norma ich skupienia w jedną większą intencję (Bratman 1987, 134). Skupianie intencji, to $\mathrm{w}$ zasadzie skupianie celów ${ }^{11}$. Norma ta ma więc ścisły związek zarówno z normą konsekwencji, jak i spójności środki-cel. Od wszystkich trzech pozostałych jednak dość wyraźnie się różni. Twierdzę, że sama teoria Bratmana raczej nie umożliwia zauważenia, na czym ta różnica dokładnie polega. Różnicę tę można dostrzec w pełni dopiero po uwzględnieniu perspektywy ściśle prakseologicznej, której najadekwatniejszą próbę stanowiła dotychczas propozycja Kotarbińskiego.

Wyżej czynione odniesienia do koncepcji norm planowania Kotarbińskiego były raczej deklaratywne; w tym miejscu uwagi na jej temat są już niezbędne. Stwierdziłem, że podobieństwo między teorią Bratmana i prakseologią Kotarbińskiego jest szczególnie wyraźne i znaczące, gdy spojrzymy na wskazane przez nich normatywne wytyczne planowania. W

9 Tu dobrze pasuje metafora tzw. łódki Neuratha, którą lubili się posługiwać (w różnych kontekstach) Quine oraz Bittner: Jesteśmy jak żeglarze, którzy muszą przebudowywać swój statek na morzu, nigdy nie mogąc rozebrać go w doku i zbudować od nowa (por. Bittner 1980, 144; Makowski 2012, 186).

10 Nie oznacza to oczywiście, że tej immanentnej predyspozycji powinniśmy bezwzględnie ulegać. Przekonuje o tym szczególnie prakseologiczna perspektywa, którą zarysowuję niżej.

11 Proviso: nie dotyczy to jednak przedmiotów pragnień jako celów. Kwestia ta wymagałaby osobnych rozważań. 
Traktacie o dobrej robocie, który jest zarysem - przypomnijmy - teorii skutecznego działania, Kotarbiński starał się zaproponować normy „dobrej roboty" dla wszelkich możliwych rodzajów działań, od elementarnych po najbardziej skomplikowane. Nie dziwi więc, że obiektem jego uwagi były również normy dobrego planu12. I to właśnie z punktu widzenia Traktatu patrząc, normy działalności planowanej, jakie proponuje Bratman, okazuja się normami prakseologicznymi, bowiem odpowiadaja w sposób elementarny za jej skuteczność. Dlaczego jest to sposób jedynie elementarny, lub - odwołując się do tytułu - minimalny? Odpowiedź jest następująca: normy planowania, na jakie wskazuje Bratman, zostały omówione (w mniej lub bardziej zaawansowany sposób) ${ }^{13}$ przez Kotarbińskiego w Traktacie (Kotarbiński 1955, 162-170), omówienie to jednakże jest tylko częścią szerszego przedsięwzięcia w postaci próby pełnej teorii norm prakseologicznych, a więc - zorientowanej na optymalizację skuteczności. Nie ma tu oczywiście miejsca na krytyczne omówienie wszystkich tych normatywnych, prakseologicznych wymogów działania ${ }^{14}$. Powróćmy zatem do norm działalności planowanej i pytania o swoistość normy skupienia intencji, na które można już dać ogólną odpowiedź. Stwierdziłem, iż różni się ona od norm konsekwencji, spójności środki-cele oraz stabilności. Różnica ta polega na tym, iż jest to - jak się wydaje - jedyna norma planowania u Bratmana, której rola uwidacznia właśnie wstępnie optymalizujący względem problemu skuteczności działania charakter. Skupianie zamiarów, to nic innego jak przykład prakseologicznie rozumianej ekonomizacji działania15. Jeśli w tym samym czasie zamierzasz iść z Gosią na kawę i zamierzasz posłuchać koncertu jazzowego, to możesz - przy odpowiednich warunkach - zamierzać wypić kawę z Gosią, jednocześnie słuchając koncertu jazzowego. Mówiąc przysłowiem: staraj się upiec dwie pieczenie na jednym ogniu ${ }^{16}$.

Obecność normy skupienia jako normy wstępnie optymalizującej i ekonomizującej nie oznacza jednak, iż teorię planowania Bratmana można

\footnotetext{
12 Zob. też dwa ciekawe eseje: Ogólne pojęcie planu oraz Walory dobrego planu (Kotarbiński 1999, 274-304).

13 Nie twierdzę rzecz jasna, iż normy te Kotarbiński wyraził w podobny sposób, co Bratman. Jest to jednak osobny problem, który omawiam w (Makowski, w przygotowaniu A).

${ }_{14} \mathrm{Tu}$ sygnalizuję jedynie, że można je wszystkie typologicznie zaklasyfikować pod czterema nagłówkami: aktywizacja, przygotowanie i organizacja, ekonomizacja oraz instrumentalizacja. Różnią się one do siebie pod względem charakteru i stopnia normatywności, co wymaga krytycznej interpretacji, której rezultat odbiega od metodologicznie neutralnej prezentacji, jaką chciał dać Kotarbiński.

15 Bratman tego wymiaru normy skupienia zdaje się nie zauważać. Sama koncepcja aglomeratywności intencji została przez niego jedynie zaznaczona. Dobre rozwinięcie (i obronę) tej idei zaproponował Zhu (Zhu, 2010), ale koncentruje się on wyłącznie na kwestii jej związku z racjonalnością.

16 Miłośnicy prakseologii wiedzą, że Kotarbiński nazywał takie powiedzenia „kryształami myśli praktycznej” - por. (Kotarbiński 1955, 329-331).
} 
potraktować jako koncepcję optymalistyczną, a koncepcję norm - jako kompletną. Bratman filozofię działania uprawia w paradygmacie ograniczonej racjonalności spod znaku Herberta Simona, co poniekąd wyjaśnia jego odejście od tendencji optymalizujących: „jesteśmy podmiotami działania o ograniczonych zasobach", jak powiada Bratman (Bratman 1987, 10). Nie jest to jednak odpowiedź satysfakcjonująca w pełni. Ponownie, zestawienie koncepcji Bratmana z propozycją Kotarbińskiego okazuje się tu pomocne. Zwrócę uwagę tylko na jedną kwestię, która wydaje mi się przesądzająca. W zestawie własności dobrego planowania w Traktacie mamy plastyczność. Norma plastyczności planowania, to inaczej wymóg czynienia go adekwatnym do warunków wtedy, gdy ulegają one zmianie (Kotarbiński 1955, 168). Stanowi ona pewną gwarancję, iż danego planu nie będziemy musieli starać się zastąpić innym, gdy tylko zmienne otoczenie empiryczne działania uczyni go nieadekwatnym. Paradoksalnie, plastyczność stoi tu więc w zgodzie ze stabilizującym aktywności praktyczne, normatywnym wymiarem psychologii podmiotowości praktycznej. Normy plastyczności nie ma jednak w koncepcji norm działalności planowanej Bratmana ${ }^{17}$. Dlaczego?

Może tak być z kilku niezależnych powodów. Tu wskażę na trzy. Po pierwsze, plastyczność trudno potraktować jako normę dla samej intencji. Założenie, że normy działalności planowanej, są wg Bratmana, również normami samych intencji, okazuje się dość istotne. Jeśli faktycznie uznalibyśmy normatywność plastyczności planowania, to musielibyśmy uznać, że normy planowania nie są tożsame z normami intencji18. Po drugie, można by ewentualnie przypuszczać, że plastyczność jest sprzeczna z inną normą planowania $\mathrm{w}$ postaci stabilności19 ${ }^{19}$ dlatego nie może być rozumiana jako norma działalności planowanej. Uwagi na temat zasadności normatywnego charakteru plastyczności raczej niweczą tę drugą ewentualność. Między plastycznością a stabilnością jest pewne napięcie, ale nie sprzeczność. Norma plastyczności planu nie oznacza, że nie może on podlegać stabilności. Między tymi normami zachodzi swoista komplementarność i sprzężenie zwrotne. Po trzecie, Bratmanowska koncepcja stabilności intencji zbudowana jest w ramach idei „nierefleksyjnej (nie)rewidowalności” intencji (Bratman 1987, rozdz. 5), a więc z założenia pomija przypadki, które dotyczą plastycznej zmiany planów, w których po prostu porzucamy zamiary z powodu zmian w naszym otoczeniu. Jakkolwiek neutralne wydaje się to pominięcie, ma ono poważne konsekwencje dla obrazu stabilności naszej psychologii w działaniu.

\footnotetext{
17 W jaki sposób normę tę można pogodzić z koncepcją Bratmana, pokazuję dokładniej w tekście (Makowski, w przygotowaniu B).

18 Ta ewentualność tłumaczy, ale nie usprawiedliwia Bratmana. Można bowiem nadal twierdzić, że plastyczność jest własnością planu rozumianego nie intuicyjnie, jako „rozrośnięta” intencja, ale już teoretycznie, jako sieć zazębiających się intertemporalnie intencji, których semantyczne związki nie są określone sztywno. Założenie to przyjmuję i rozwijam w (Makowski, w przygotowaniu B).

19 Taką próbę krytyki zaproponował David Copp (zob. Makowski, w przygotowaniu B).
} 
Plastyczność, rozumiana jako umiejętność radzenia sobie ze zmianami w otoczeniu naszych planów, jest bowiem gwarancją, iż nasze plany nie będą inercjalne, gdy działamy $\mathrm{w}$ otoczeniu niestabilnym. Plastyczność zatem koryguje inercję intencji; inercja intencji jest bowiem drugą stroną medalu stabilności planowania, cf. (Bratman 1987, 16-17, 60). Zatem, każdy plan musi być stabilny, ale $w$ warunkach niestabilnego otoczenia tę stabilność może gwarantować jedynie plastyczność.

Powyższe ogólnie zarysowane uwagi pokazują, jak myślę, dostatecznie wyraźnie, że istnieją solidne podstawy, by nie rezygnować z optymalizujących aspiracji w badaniach nad teorią planowania ${ }^{20}$.

Normy działalności planowanej, na jakie wskazuje Michael Bratman, zaproponowałem w niniejszym tekście usytuować w kontekście prakseologii wywodzącej się wprost z prac Kotarbińskiego. Zabieg taki pozwolił wykonać jednocześnie dwie rzeczy. Po pierwsze, wskazałem nieznany - z perspektywy filozofii intencji, która charakteryzuje podejście Bratmana - zorientowany na skuteczność, prakseologiczny horyzont rozważań na temat działalności planowanej. Po drugie, określiwszy jedynie minimalistyczne aspiracje amerykańskiego filozofa $\mathrm{w}$ ramach eksploracji tego horyzontu, zwróciłem uwagę na zasadność krytycznego wykraczania poza ów minimalizm. Jedno i drugie powinno stanowić zachętę do dalszych badań - już w ramach prakseologii, której kompas orientuje badania optymalistycznie, wskazując jednocześnie na filozofię intencjonalności jako jej szkielet.

Warto też zauważyć, że daleko idące zbieżności między prakseologiczną koncepcją norm działalności planowanej a sformułowaną całkowicie względem niej niezależnie koncepcją planowania Bratmana pokazują, że potencjał prakseologii - uznawanej przez gros polskich zwolenników tej dyscypliny za system skończony i wymagający jedynie popularyzacji - wymaga ponownego przepracowania.

\section{Bibliografia}

Bittner, R. 1980. What Reason Demands, transl. Th. Talbot, Cambridge: Cambridge UP.

Bratman, M.E. 1987. Intention, Plans, and Practical Reason, Cambridge: Harvard UP.

Kotarbiński, T. 1955. Traktat o dobrej robocie, Warszawa, Ossolineum.

Kotarbiński, T. 1999. Dzieła wszystkie: Prakseologia, Część I, Ossolineum.

Makowski, P. 2012. Po metaetyce. Dobro i powinność $w$ etykach naturalistycznych, Kraków: TAiWPN Universitas.

20 Aspiracje te nie muszą też oznaczać zerwania $\mathrm{z}$ modelem racjonalności ograniczonej. 
Makowski, P. w przygotowaniu A. "Does Praxiology Rest on a Mistake?".

Makowski, P. w przygotowaniu B. "Intention Inertia and the Plasticity of Planning".

Zhu, J. 2010. "On the principle of intention agglomeration". Synthese Vol. 175: 89-99. 
Piotr Makowski

\title{
Bratman and a Minimal Praxiology
}

\begin{abstract}
The paper is an introductory essay to the Polish translation of M.E. Bratman's paper The Fecundity of Planning Agency. Instead of summarizing the main drifts of Bratman's work, the author tries to show a few important parallels between his approach to action theory and the so-called praxiology (or 'theory of efficient action') proposed by Tadeusz Kotarbiński. It occurs that there are important similarities between their approaches both to specific problems in action theory (as: concept of an agent, the role of Buridan's Ass, or mind-infusion of actions) and to the general question how to understood agency (norms of planning). A brief presentation of these similarities gives two central results. Firstly, it allows to interpret Bratman as a kind of praxiologist, and, secondly, it shows that praxiological thinking proposed by Kotarbiński is still a vital perspective in contemporary action theory.
\end{abstract}

Key words. Michael E Bratman, Tadeusz Kotarbiński, philosophy of agency, praxiology, planning theory of intention.

Ethics in Progress (ISSN 2084-9257). Vol. 4 (2013). No. 2. pp. 78-86. 